\title{
Lumen
}

Selected Proceedings from the Canadian Society for Eighteenth-Century Studies

\section{Proverbs and the Language of Control in Clarissa}

\section{G. D. Fulton}

Volume 14, 1995

URI : https://id.erudit.org/iderudit/1012510ar

DOI : https://doi.org/10.7202/1012510ar

Aller au sommaire du numéro

Éditeur(s)

Canadian Society for Eighteenth-Century Studies / Société canadienne d'étude du dix-huitième siècle

ISSN

1209-3696 (imprimé)

1927-8284 (numérique)

Découvrir la revue

Citer cet article

Fulton, G. D. (1995). Proverbs and the Language of Control in Clarissa. Lumen, 14, 79-96. https://doi.org/10.7202/1012510ar d'utilisation que vous pouvez consulter en ligne.

https://apropos.erudit.org/fr/usagers/politique-dutilisation/ 


\section{Proverbs and the Language of Control in Clarissa}

Samuel Richardson's Lord M. is no philosopher, but in his belief that proverbs embody and deploy with striking force 'the wisdom of nations,' he agrees with his better informed contemporaries, namely those philosophers who argued for the collective development and socially formative power of language. ${ }^{1}$ Critical comment on this 'comic prattler of omnipurpose platitudes' ${ }^{2}$ has exhausted itself on Lord M.'s 'proverbialism' and concomitantly limited intellectual capacity; in this it has followed the lead of Richardson's list of 'Principal Characters', where (in the first edition of the novel) Lord M. alone is characterized by speech habit (as 'a nobleman of middle genius and a great proverbialist'). ${ }^{3}$ This treatment is also supported by a disdainful attitude to proverbs widely shared among early readers of the novel, for whom proverbs were features of social dialect, language affiliating a speaker with primarily two social categories, the rustic and the vulgar.

But Lord M. is not the only character to use proverbs - Richardson marks a surprising affinity between Lovelace and his uncle through them - and the proverb is a significant interactive strategy in the novel, as well as an aspect of individual style. Along with other verbal strategies used in the hope of controlling others, it exemplifies what Basil Bernstein has called a 'restricted code', where language expresses group solidarity rather than personal individuality. ${ }^{4}$ In this brief study, Lord M.'s use of proverbs will be related to the Harlowe family's verbal strategies for controlling Clairssa. I wish to demonstrate the merits of Bernstein's theory of code for literary (historical) stylistics and also suggest that stylistic study can play an important role in any renewed historicism focusing on the relation of text and context. ${ }^{5}$ I here read 'style' not primarily as a property of individuals but as part of a dynamic process in which self emerges in contexts that are always, as Bakhtin argues, encountered first as the language of others. ${ }^{6}$ Not merely a marker of personal idiosyncrasy, the proverb no less than the pronoun expresses solidarity and exercises power.

Richardson's characters use proverbs just when, according to James Obelkevich (who cites Lord M.'s awareness of this attitude), the edu- 
cated classes had abandoned proverbs and banned them from polite literature and conversation. ${ }^{7}$ Even allowing for the relaxed standards of politeness that familiar letters permit, Lord M. seems deliberately to flout the conversational rule Steele lays down for young Dick Lizard in Guardian 24:

Nothing, however, is more insupportable to Men of Sense, than an empty formal Man who speaks in Proverbs, and decides all Controversies with a Short sentence. This piece of Stupidity is the more insufferable, as it puts on the Air of Wisdom. ${ }^{8}$

Where Steele opposes 'sense' and 'formality', Lord Chesterfield opposes 'fashion' and 'vulgarity' when he cautions Stanhope that,

Vulgarism in language is ... [a] distinguishing characteristic of bad company and a bad education. A man of fashion avoids nothing with more care than that. Proverbial expressions and trite sayings are the flowers of the rhetoric of a vulgar man. Would he say that men differ in their tastes; he both supports and adorns that opinion, by the good old saying, as he respectfully calls it, that what is one man's meat is another man's poison ... A man of fashion never has recourse to proverbs and vulgar aphorisms. ${ }^{9}$

In the introduction to Swift's Complete Collection of Genteel and Ingenious Conversation, Simon Wagstaff directs his readers to 'learn by all Means to distinguish between Proverbs, and those polite Speeches which beautify Conversation: For, as to the former, I utterly reject them out of all polite discourse. ${ }^{10}$ The Collection that follows presents conversations stitched together almost entirely out of proverbs and other vulgarisms, so Swift slyly includes in Wagstaff's introduction just the kind of specious justification his speakers would be likely to approve:

I acknowledge indeed, that there may possibly be found in this Treatise a few Sayings among so great a Number of Smart Turns of Wit and Humour as I have produced, which have a proverbial Air. However, I hope it will be considered, that even these were not originally Proverbs, but the genuine Productions of superior Wits, to embellesh and support Conversation; from whence, with great Impropriety ... they have most injuriously been transferred into proverbial Maxims; and therefore ought in Justice to be resumed out of vulgar Hands, to adorn the Drawing-Rooms of Princes, both Male and Female, the Levees of great Ministers, as well as the Toylet and Tea-Table of the Ladies. ${ }^{11}$

English attitudes to proverbs were not always disparaging, however, particularly in writing addressed to middle-class readers, and several 
comments praising them imply that as markers of group affiliation in Clarissa they may bear more complex interpretation. When they are less anxious about the social status of their speakers and the values they represent, or when the user of proverbs does not pretend to good breeding or polite wit, English writers often take a more positive view. John Hughes praises Sir Roger L'Estrange as 'a perfect Master of all the Idioms and Proverbial Expressions which are peculiar to our Tongue; these he often applies happily enough, tho' sometimes not without Affectation. ${ }^{12}$ Writing as Isaac Bickerstaff in the 'From my own Apartment' section of Tatler 96, Addison advises 'men of real merit' to avoid singularity in appearance and behaviour with the flourish, 'For, as we old Men delight in Proverbs, I cannot forbear bringing out one on this Occasion, That good Wine needs no Bush. ${ }^{13}$ When Steele introduces into Spectator 509 a letter from a correspondent urging honest trading, he makes allowances for the writer's background as follows:

My present Correspondent, I believe, was never in Print before; but what he says well deserves a general Attention, tho' delivered in his own homely Maxims, and a Kind of Proverbial Simplicity; which Sort of Learning has raised more Estates, than ever were, or will be, from Attention to Virgil, Horace, Tully, Seneca, Plutarch, or any of the rest ... ${ }^{14}$

This mixture of positive and pejorative attitudes suggests that proverbs were to be rejected or allowed according to context: rejected in the mode of anxious self-scrutiny enjoined on those who aspired to polite company, but allowed in contexts where social solidarity (or at least sympathy) could be presumed. Thus, when Lady Mary Wortley Montagu declared that 'old Lord M. talks in the style of a country justice,' Samuel Richardson might have agreed, although with quite a different idea of what this might mean. ${ }^{15}$

The strongest reason for criticizing Lord M.'s proverbs and considering him just a 'middle genius' in moral perception, is that while his proverbs are relevant to the issues at stake in the novel, their language is so general that they do not engage closely the language in which other characters address those issues. By depending almost exclusively on proverbs for his moral language, Lord $M$. isolates himself linguistically from others, unwittingly emphasizing his limited understanding of the novel's central problems, compromising his ability to engage closely with the particulars of situations and preventing his views from being taken seriously. Several of the proverbs in his letter to Belford might stand as mottos to events in the novel - 'when a thing is done advice comes too late' (606), 'delays are dangerous' (607), 'a handful of good life is better than a whole bushel of learning' (607) - but they understate the novel's tragic 
seriousness, and key terms like 'delays', 'advice' and 'learning' simplify considerably the complex problems to which they refer. Other proverbs are so inadequate as to seem shallow, if not complacent. In a novel which opens with an injunction to confirm or deny 'report', where the opinion of the 'world' is always to be resisted, and where 'wisdom' seems either lacking or impotent, 'what everyone says, must be true' and 'a word to the wise is enough' (606) are thoroughly inappropriate expectations.

This letter was expanded considerably by the third edition, and Lord M.'s sententiousness increases proportionally. Several of the additions call into question his own behaviour and the grounds on which he thinks proverbs will effect his persuasive purpose. Although he has heeded the advice of some of his proverbs, Lord M.'s state of health now demonstrates that 'Young men's frolics, old men feel, ${ }^{16}$ and his moral authority is compromised significantly when, just before the trial scene in which he addresses Lovelace in high indignation, he laughs at Lovelace's accounts of rakish exploits and at his recollection of having once considered seducing his cousins. ${ }^{17}$ The scene is related only by Lovelace, but his description of his uncle and the ironic reflection that follows seem justified:

The old peer has been a sinner in his day, and suffers for it now: a sneaking sinner, sliding rather than rushing into vices, for fear of his reputation: or, rather, for fear of detection and positive proof; for these sort of fellows, Jack, have no real regard for reputation. (1023)

Proverbs have not kept Lord M. from his pleasures, or from appreciating the illicit pleasures of others; the 'sneaking' and 'sliding' have been done under cover of moral language allowing wide scope for self-indulgence. While speaking proverbs, he has been able to avoid the strenuous task of connecting moral language with the living of life.

Proverbs are less frequent in Lord M.'s letter to Lovelace (which was revised little by the third edition), but this comparative self-restraint is lost on his nephew, who considers the letter a 'farrago of nonsense' so full of 'pop-guns' he cannot show it to Clarissa 'without exposing the head of our family for a fool' (663). Lovelace is likely to consider as irrelevant, or at best remote, those proverbs which apply to him personally. He aims to belie the wisdom of 'It is a long lane that has no turning' (664) and 'all your wild oats will be sown [on marriage]' (665) (a superficial view the Harlowes have also taken - 200); he does not believe 'No man is always a fool, every man sometimes' (664), while 'The more noble anyone is, the more humble' (664) must remind him of Clarissa. He intends to 'Let your actions praise you' (665) - in ways Lord M. is far from intending - and two other proverbs later prove more apposite to him than he imagines. 'Worth is 
best known by want', which Lord M. applies to his own experience, becomes relevant to Lovelace's, actually understating the fervour with which Lovelace comes to believe (as he does in his last words) that Clarissa is his only hope for salvation; and his persistent disregard of Belford's admonitions and his eventual fate confirm the 'great wisdom' of Lord M.'s 'God send me a friend that may tell me of my faults: if not, an enemy, and he will' (664). Clarissa, of course, would have responded sympathetically to Lord M.'s letter, making the applications needed for the proverbs to persuade. Lovelace's best reason for not showing it to her is that parts of it would underscore the hopelessness of her situation, in which she must depend on an implacable man to 'forgive and forget' her family's actions, a man she has so far been unable to move 'by strong arguments and gentle words' (664).

As a mode of interaction proverbs depend for their relevance, application and authority less on inherent formal qualities than on a large measure of agreement between addresser and addressee. Because the language of Lord M.'s proverbs is general and Lovelace participates in its application, refusing to apply or misapplying them as he pleases, they cannot strike him forcibly as an unexpectedly apposite analysis of events, nor can they persuade him that Lord M. possesses unusual penetration. What authority they bear will derive only from the respect paid to proverbs as a whole within the shared cultural context, and Lovelace, when it serves his sense of singularity, chooses to share no attitudes with anyone. If Lord $\mathrm{M}$. is foolish for anything, it is for not understanding this and for hoping to achieve agreement with Lovelace through a rhetorical genre that presupposes a shared perspective. He fails to persuade Lovelace not just because he is personally shallow and hypocritical: community is put seriously in question throughout Clarissa, so that language which in other contexts might signal forms of solidarity in this novel often strives unsuccessfully to establish it. Neither family nor society share assumptions and sense of common purpose to such an extent that 'a word to the wise' can be 'enough'.

Depending for their pragmatic force on implicit rather than explicit reference to the situation they would influence, proverbs exemplify 'restricted code', a concept Basil Bernstein developed (along with its counterpart, 'elaborated code') 'to formulate the regulative principles which ... underly implicit and explicit forms of communication. ${ }^{18}$ In the work of Bernstein and his associates, the abstract category of code is one part of a sociological theory developed to understand the transmission of culture and the reproduction of social structure. This theory is unusual for the importance it places on language (hence its classification as 'sociolinguistic') and although the most extensive research so far conducted with the concept of code has investigated socially differenti- 
ated patterns of educational achievement, Bernstein has insisted that in itself a restricted code is not a sign of linguistic or cognitive deficiency: 'A restricted code contains a vast potential of meanings. It is a form of speech which symbolizes a communally based culture. It carries its own aesthetic. ${ }^{19}$ The theory also posits significant relations between code and social class, although, as Bernstein insists (contrary to widespread misconception of his work), 'Restricted codes are not necessarily linked to social class. They are used by all members of society at some time. The major function of this code is to define and reinforce the form of the social relationship by restricting the verbal signalling of individual experience. ${ }^{20}$ The rest of this essay will explore these aspects of restricted code.

In Clarissa, restricted code correlates not with social structure as such, but with allegiance to family and the grouping of individuals according to consciously held beliefs. Instances of restricted code express 'code' in the non-technical sense of shared ideology or codes of values, while also striving to control behaviour and establish (or maintain) relative status. Where relevant, I will draw upon a further pair of concepts from Bernstein's sociology: namely those of positional appeals and personal appeals, which relate to the two different types of control exercised over children and which often use restricted and elaborated coding of experience respectively. For the purposes of this discussion, positional appeals are attempts to control an individual through her status within a social group (typically the family), while personal appeals are attempts to control an individual through feelings and principles. ${ }^{21}$ The focus will be on the deliberately narrowed ranges of lexical and grammatical selection which realize restricted code in the novel, usually in situations where language is used for purposes of control, and it is the relative degree of restriction or elaboration that is important, not the simple presence or absence of canonical markers of either one. As Bernstein has reiterated, codes are dispositions in the use of language, not distinct varieties of language, and it is as indices of codal orientation that restricting or elaborating features of language express solidarity and enable control.

It was as an arbitrarily applied strategy of control, reducing whatever was individual to what was declared to be typical, that proverbs became repugnant to Lovelace, who claims that whenever he requested anything of Lord M. as a boy his uncle responded according to whichever proverb first came to mind. This, Lovelace says, gave him such a distaste for the 'wisdom of nations' that he agreed with his tutor to read the Bible only on condition that he could omit the Book of Proverbs. But when at the close of this account he invites Belford to share his dismissive attitude through a proverbial turn of phrase himself - 'Well, but let us leave old saws to old men' (611) - Richardson signals an unacknowledged affinity with his uncle, a return of the verbally repressed in Lovelace's prose. 
Elsewhere, in spite of his sneers at Lord M.'s 'wisdom of nations' (663) and his supposition that Lord M. has not written because he is 'Hunting after more wisdom of nations,' (691) Lovelace several times cites proverbs and attributes them to Lord M. without stigmatizing them, and he uses proverbs approvingly himself. ${ }^{22}$

In one remarkable passage in a letter from Hampstead, Lovelace even reverses his opinion:

I will now give thee the substance of the dialogue that passed between the two women and the lady. Wonder not that a perverse wife makes a listening husband. The event, however, as thou wilt find, justified the old observation, that listeners seldom hear good of themselves. Conscious of their own demerits (if I may guess by myself: There's ingenuity, Jack!), and fearful of censure, they seldom find themselves disappointed. There is something of sense, after all, in these proverbs, in these phrases, in this wisdom of nations. (790)

Forced by circumstances into an activity beneath the character of a gentleman, Lovelace explains his action by a generalization that blames Clarissa for it in the false terms in which he has presented their relationship to the people at Hampstead. He finds the 'wisdom of nations' acceptable here for several reasons. At Hampstead, he relies upon the stereotypes of long-suffering 'husband' and 'perverse wife' to motivate the women there to help him, controlling the situation through the assumptions with which he persuades others to read it. The reflections on womankind and on human nature which the Hampstead women inspire are, unfortunately for Clarissa, only too well justified by events. Satisfaction with how well his plot is working allows Lovelace to relax from his fanatical insistence on originality and on making a way for himself off the beaten road, allowing Richardson to suggest that Lovelace is not so radically different from others as he thinks. But at the same time Lovelace cleverly interpets the proverb through the moral language associated with Clarissa ('conscious', 'demerits', 'ingenuity', 'censure'), connecting the 'old observation' more closely with the language of the novel than Lord M. ever does his proverbs, and he candidly applies the proverb to himself. This ingenuous application makes a point for Richardson (about the psychology of 'listeners'); yet it is also, for Lovelace, mere verbal play undertaken as an end in itself. The claim 'There's ingenuity ...' occurs as a parenthesis within a parenthesis, and the development of the passage (suggesting the rapid movement of a writer monitoring and commenting on his writing) is toward a final generalization on proverbs. This development enacts such a high degree of self-reflexivity in the process of writing, with clauses commenting on previous ones, that Lovelace seems more interested in reflecting on 
proverbs than in what he admits about himself, falsely confident the figure exercising control is the only party not himself controlled by this language.

Once, in the presence of his assembled family, Lovelace demonstrates a shrewd understanding of how the proverb's restrictive coding of experience can serve his purposes in a context where it is highly valued. Attempting to disarm the charges Clarissa has made in a letter to his family, he uses two proverbs to translate tactically from Clarissa's precise moral language into the more general moral language of Lord M., hoping this will persuade the family to his own estimate of what Clarissa has described:

The lady says, 'She has been dishonoured ... by means that would shock humanity to be made acquainted with them.' She is a very innocent lady, and may not be a judge of the means she hints at. Over-niceness may be under-niceness: have you not such a proverb, my lord? - tantamount to, One extreme produces another! - Such a lady as this may possibly think her case more extraordinary than it is. (1032)

The different degrees of certainty expressed in these two 'proverbs' (tentativeness expressed through the modal verb 'may be' in the first, certainty expressed by their being no modal verb in the second) favour his appeal: the proposition with the closest verbal relation to Clarissa, the claim about 'niceness' which represents her experience more fully, admits of doubt; the more general proposition about 'extremes' admits of none. Lovelace's final claim is modalized as well ('Such a lady as this may possibly think ...') because he is making Clarissa responsible for the assessment of 'her case' as 'more extraordinary than it is' and such an outrageous assertion, like the claim that she 'may not be a judge of the means she hints at', must be made tentatively to the family if at all. Modality, expressing a speaker's opinion of the likelihood or 'usuality' of what is asserted, is one part of the grammatical resources for handling interpersonal relations in English. ${ }^{23}$ The other major component of this dimension, mood, is also important in this passage, in the shift from declarative to interrogative, and the effect is consistent with the shifts in modality: Lord M. is being encouraged to agree with Lovelace's assessment. The interpersonal dimension is prominent in this passage because in the immediate situation Lovelace is attempting to influence attitudes, to win the others to his side; given repeated instances of such prominence across the whole novel, it can be argued that it occurs not just so that one character may act on others through his speech, but also to direct readers' attention to the important questions of how they think of Clarissa and how they assign responsibility for actions. 
The 'proverb' on 'over-niceness' is more closely related than most to the language of the rest of the novel, but it is yet another instance of Lovelace's self-interested reading of situations and behaviour, stemming from his persistent attempt to disturb and displace assumptions. If the family accepts this proposition he will have defined the issue under debate as over-delicacy in Clarissa and thus enabled himself to manage the debate within assumptions they will have difficulty questioning. Lovelace's account of the family's reaction to these claims goes into considerable comic detail, and to judge from this account it is as if his tactic has made words irrelevant and reduced the situation to a contest of expressive gestures. In this contest there can be no reference beyond an immediate situation and present feelings, and Lovelace can believe he triumphs either because he evokes assent - his 'humorous undaunted' manner, he says, forces smiles from his cousins (1032) - or because in his account he assigns the others' reactions meanings which favour his position. It is significant that the criticism which does affect him is made by Lady Sarah, the centre of moral authority in the scene, who contests his claims not by reacting with emotional expressions of disdain or disgust, but by scrutinizing his language as carefully as Clarissa would herself. She refutes his insinuations with a restatement of Clarissa's public character, an elaborated focus on her personality and values (which he cannot deny), and she forces him to reconcile his actions with that (1033). This is how Lovelace's attention can be commanded and how he can be compelled to admit his actions have been wrong, not by proverbs.

Nonetheless, for all his imperviousness to it, for all the self-conscious irony of such a deliberate attempt to sway others through a form of language they trust, his uncle's proverbialism has affected Lovelace deeply. This is nowhere more apparent than in the maxims of his 'rake's code', the literary quotation 'Every woman is at heart a rake,' 'importunity and opportunity, no woman can resist' and 'once subdued, always subdued.' Allowing no distinctions, these propositions bond rakes one to another in shared allegiance to the terms through which they master women. Lovelace thinks to distinguish himself by testing these on Clarissa, all the while imagining he himself is no way bound by them. But the logic of the implicit and communal, which Lovelace believes he can deploy or suspend at his pleasure, is absolute: Lovelace stakes his claim to personal significance and glory in 'rakish annals' on a test of propositions which, if true, render his entire libertine persona utterly commonplace. Physicality is central to his trial of Clarissa, yet it is anathema to his sense of self and no part of his proposed pleasure. As James Grantham Turner has shown, libertines who interpret physicality within a materialist philosophy of involuntary impulse sooner or later discover that the selves they believe transcend common morality are 
subsumed as small functions within a supervening pattern of action and reaction. ${ }^{24}$ They discover themselves, as Lovelace does, 'a machine at last, and no free agent' (848). The quasi-proverbial form of the maxims constituting the rake's code is a stylistic clue to this paradox, predicting not a unique Lovelace, but the levelling of pursuer and prey without distinction into the wide range of their application. Lovelace can subvert the force of proverbs with which Lord M. attempts to control him, but he does not realize until he is within its grasp the full logic of the restricting rake's code he uses as an instrument of dominance himself. It is a mark of Clarissa's sharper intelligence and an aspect of her final triumph that she uses a similar strategy fully aware of what it will cost.

The Harlowes' language for controlling Clarissa is more explicitly relevant to the issues which concern her in the rest of the novel than are Lord M.'s proverbs to Lovelace's experience, but as a strategy for enforcing their collective will it fails as completely. All their tactics to force their assumptions onto her situation provoke Clarissa to question and reject the selfishness she sees to be motivating them. While they do not shift so consistently into a restricted verbal code as Lord M. does, the Harlowes operate both a positional and a personal strategy of control, and the contrast between more restricted and more elaborated language is important for these attempts to influence the 'rebel daughter'.

The Harlowes' positional appeal is a simple demand that Clarissa as daughter dutifully obey her father. The prejudices and hypocrisies which constitute the Harlowe moral code are most evident in this appeal; at its harshest it is expressed by Mr. Harlowe himself in speech restricted almost exclusively to terms of family relationship arranged in the grammatical forms of brief exclamations, elliptical interruptions of others, imperatives and declarations of his will. His speeches in the scenes where Clarissa is instructed before her visit to Anna and left alone with him shortly after her return offer several examples of these features. In the first scene, Mr. Harlowe sits in judgement on a verbal contest playing before him, interjecting twice with 'Son James!' $(57,58)$ and with 'No more! - No more, of either side ... You are not to receive the visits of that Lovelace, though - Nor are you, son James, to reflect upon your sister. She is a worthy child' (57). Alone with Clarissa, he is even more vehement, hardly allowing her to finish a sentence, himself uttering in places only a few complete grammatical sentences over the course of several exclamations: 'No protestations, girl! — No words - I will not be prated to! - I will be obeyed! - I have no child - I will have no child, but an obedient one! ... No expostulations! - No but's, girl! - No qualifyings! - I will be obeyed, I tell you! - and cheerfully too! - or you are no child of mine!' (64-65). Clarissa can be counted upon to retrieve the relevant meanings of these expressions from context, but not 
to submit tamely to the kind of relationship which, as instances of restricted code, these speeches symbolize and strive to enforce. ${ }^{25}$

The other family strategy, a personal appeal through the values that define Clarissa as a distinct person, attempts to control her through her own principles. In Antony's letter, features realizing restricted code (such as his reiterated 'Mind that') are threaded through more elaborated formulations:

And so a noted whoremonger is to be chosen before a man who is a money-lover! Let me tell you, niece, this little becomes so nice a one as you have been always reckoned. Who, think you, does most injustice, a prodigal man or a saving man? - The one saves his own money; the other spends other people's: but your favourite is a sinner in grain, and upon record ... What names will perverseness call things by - A prudent man, who intends to be just to everybody, is a covetous man! - while a vile, profligate rake is christened with the appellation of a gallant man, and a polite man, I'll warrant you! (154)

Central to this passage are questions of definition carried out through a restricted stock of adjectives deployed as single modifiers in phrases expressing stable categories no right-thinking daughter loyal to family values can confuse. In the letter which provokes this response, Clarissa uses several tactics (such as conditional dependent clauses - 'But, sir, if I am prepossessed, what has Mr. Solmes to hope for?'(151)) to entertain as hypotheses some parts of the family's case against her and then provokingly point out flaws or absurdities in it. Taking this particular hypothesis as a fact, and thinking his appeal to her reputation will determine the response he desires, Antony invites Clarissa to judge of a general case (one of her favourite activities), to reconsider the two men, and choose again ('Who, think you ...?'). Since she can only agree that 'a saving man ... saves his own money' and 'a prodigal man ... spends other people's,' Antony assumes that the matter admits of no doubt. He knows that Clarissa can refuse to apply his terms to Solmes and Lovelace, so although his own argument depends on selective characterization, in effect on giving the two men false identities, he attempts to forestall this refusal by rebuking Clarissa (as 'perverseness') for making false identifications of the two men herself: 'A prudent man ... is a covetous man', 'a vile, profligate rake is ... a gallant man, and a polite man'. It is not definitions of Solmes and Lovelace that are ultimately important, however, and Clarissa can destroy the basis for this appeal by refusing to accept the family's definition of her. She will sacrifice her reputation readily when she understands that preserving it might compromise her power to choose according to her judgement and her principles: if it would help, she would admit to the family as freely as she does to 
Lovelace's women in the sherriff's officer's house, 'I am not nice now.'(1060). ${ }^{26}$

Father and uncle use more and less restricted code as an unmarked or 'natural' expression of patriarchal privilege, or at least they wish they could. To their chagrin, paternal control has already been compromised in the family, however, by Clarissa's grandfather willing property according to personal as well as positional considerations, bequesting an estate to Clarissa personally so that a favourite granddaughter might defend her individuating excellence from collective resentment already mounting against it. ${ }^{27}$ This is why the Harlowe males make their case with such peculiar, Jehu-driving vehemence: their use of restricted code does not express shared assumptions, it attempts to enforce them, especially on the Harlowe women, who must take up the positions offered them or suffer the consequences. When its own attempts fail and the family enlists Mrs. Norton in its cause, it engages in both a personal and a positional appeal at once, for as the mentor who has formed Clarissa's code of values and as one 'for whom they know [she has] even a filial regard' (177), Mrs. Norton can appeal at once to her senses of moral and filial duty.

Clarissa's relation to these two kinds of attempts to control her behaviour is paradoxical and self-divided. Although no redefinition of filial duty can persuade her into marriage with Solmes, she performs that duty scrupulously, even when doing so lays her open to greater family pressure. Once she is out of Harlowe Place and in no danger from Solmes, however, the idea that 'A father [would have condescended] to KNEEL to a daughter!' (506) moves her profoundly, indicating at what fearful cost she has maintained her right to 'aversion' (506), to 'thinking, weighing, reflection', 'the finer sensibilities' (507) at the core of her self-understanding. That she imagines the event in the family's restricted coding ('a father' and 'a daughter' without individuating features) suggests both Clarissa's awareness that the action would have been meaningful only as one move in a struggle for control, as well as her great difficulty in thinking at all of the unprecedented reversal of power relations the action would have expressed. Although her father has cursed her, Clarissa restates the family's restricted notion of 'duty' in her own elaborated code, in carefully individuated maxims she thinks consistent with the code of virtue that is the basis of her relationship with Anna - she even deploys this notion of duty as a weapon in the struggle with Lovelace. More seriously, she refuses to pursue the possibility of securing herself away from Lovelace (a possibility created by her personal relationship with Anna) largely because doing so would involve Anna in disobeying her mother. Forced by her family into action, Clarissa courageously rejects the abuses of a patriarchal order she knows, but once beyond the family's reach she timidly refuses to venture on an 
alternative to that order. If there is any indication she longs to flee (like Blake's Thel) away from experience and back to the security of her former state of innocence or any unwarrantably squeamish behaviour, it is her wish that she could accept the family coding of experience, become again a 'dutiful daughter', which prevents a full commitment to her friendship with Anna, not (as has often been claimed) her attitude to sexuality. ${ }^{28}$ Although Anna and Clarissa are praised for the 'nobility' of their friendship (as contradicting male expectations), Richardson's choosing not to give that friendship a larger role in determining Clarissa's destiny suggests how serious was the problem of there being no viable models of exclusively female community, and it may indicate a fundamental unwillingness (or inability) on his part to challenge the assumption that women should be daughters and wives essentially, friends only accidentally. ${ }^{29}$ Clarissa remains loyal to a positional model in which social roles and relationships set boundaries on behaviour regardless of personal inclinations; Anna cannot persuade her to construct roles and relationships on the basis of the personal.

Although its expression is often brutal and its implications are always ugly, the family's language of control sticks deep in Clarissa. She cherishes the word 'child' from her mother's lips - 'And my mamma said, let the child, that was her kind word, be heard' (59) - in her mad papers, she longs to be again a dutiful child and contrite sister, and when she makes a new identity to repair the damage that has resulted from her disobedience, one of her means to do this is to take up the language of filial duty and express through it a meaning the Harlowes have tacitly ignored - obedience to her superior duty. The allegorical letter Clarissa sends to Lovelace uses the terms of family relationship to express devotion to the will of her heavenly rather than her earthly father, and it expresses as well a new sense of urgency, an impatience with her mortal life inspired by new knowledge of the significance of death. In religious meditations made through selection and minimal adaptation of biblical quotation, in the biblical verses, symbolism and dating of her coffin, she makes a restricted code of her own, expressing through it a yearning for family both powerful and powerfully ironic. Clarissa's careful preparation for death indeed creates a new 'family' around her, a self-selected community cohering through shared admiration of a secular saint and the values she represents, and it demonstrates the great power of restricted code, its capacity to release the subject from the anxious burden of making personal meaning through means merely personal, to secure and ground the self within an orientation fully understandable only to those who share it. ${ }^{30}$ But Clarissa also prepares herself for a Harlowe family place that has, as Moll Flanders says of Newgate prison, long expected her, that 'vault of her ancestors' where she would have con- 
sented to be bricked up, that place from which her final work on the family cannot reform it as she wishes, only shake it to its foundations.

Much more could be said about the clash between personal and positional orientations in Clarissa; more examples of contrasting elaborated and restricted codings of experience expressing that clash could be discussed. The fact that both Lovelace and Clarissa at some time choose restricted code to build positional relationships, a strategy which at other times they are well able to criticize, suggests an uneasy tension between often incompatible attractions of singularity and solidarity. Through them, Richardson offers an ambivalent perspective on what was a wider social process in eighteenth-century England, a transition from positional to personal relationships in which changes in middle-class family life were especially important, and of which novels are significant agents and witnesses. ${ }^{31}$ The longer they are subjected to serious critical reading, the more the novels of this century are given to answer for, and this essay's theme can be traced through a good deal of well-informed speculation. Ian Watt relates Richardson's choice of the epistolary form to 'the transition from the objective, social, and public orientation of the classical world to the subjective, individualist, and private orientation of the life and literature of the last two hundred years'; according to John Richetti, 'Suffering and confused female characters in early fiction enact ... a cultural crisis and enormous ideological transition, the privatization and fragmentation of experience'. Work by Lawrence Stone on companionate marriage, by Katherine Green on the courtship novel, and by Nancy Armstrong on novelistic redirection of male desire and the gendering of private and public space has established a theoretical context in which Richardson's treatment of personal relations seems particularly significant. ${ }^{32}$ The challenge for criticism is how to relate the reading of literary texts to such a wide series of interrelated transformations, to test whether (and how) individual texts can (or cannot) be read in relation to social change. The concepts of restricted and elaborated code have much to offer, especially for investigating the verbal enactment of positional and personal orientation. What they suggest about the aspects of style in Clarissa considered here is twofold: rebels never completely escape the habits of community they scorn, and community can be sought only through the reworking of verbal strategies by which it has been oppressive.

\section{G. D. FULTON}

University of Victoria 


\section{Notes}

1 This philosophy of language is discussed in Nicholas Hudson, 'The Individual and the Collective in Eighteenth-Century Language Theory', Man and Nature/L'Homme et la Nature 10 (1991): 57-66.

2 Anthony Winner, 'Richardson's Lovelace: Character and Prediction', Texas Studies in Literature and Language 14 (1972): 58, n. 9.

3 Samuel Richardson, Clarissa, or The History of a Young Lady, ed. Angus Ross (Harmondsworth: Penguin, 1985) 37. Future quotations will be cited by page reference in the text.

4 Proverbs are considered in this way in Roger D. Abrahams, 'A Rhetoric of Everyday Life: Traditional Conversational Genres', Southern Folklore Quarterly 32 (1968): 44-59.

5 For a discussion of this possibility see Robert D. Hume, "Texts Within Contexts: Notes Toward a Historical Method', Philological Quarterly 71 (1992): 69-100.

6 Bernstein's work is frequently misunderstood and misrepresented in sociolinguistics; see Paul Atkinson, Language, Structure and Reproduction: An Introduction to the Sociology of Basil Bernstein (London: Methuen, 1985). His theory of code is rarely cited in the sub-discipline now settling on the name 'historical sociolinguistics'. There is a brief discussion in Elizabeth Closs Traugott and Suzanne Romaine, 'Some Questions for the Definition of "Style" in Socio-Historical Linguistics', Folia Linguistica Historica 6 (1985): 17-18; one brief, dismissive mention in English in Its Social Contexts: Essays in Historical Sociolinguistics, ed. Tim William Machan and Charles T. Scott (New York and Oxford: Oxford UP, 1992) 174; one mention only in Carey McIntosh, Common and Courtly Language: The Stylistics of Social Class in 18th-Century English Literature (Philadelphia: U of Pennsylvania P, 1986) 11, n. 2. Bakhtin's theories of utterance and individuality, and of the relation between literary (especially novelistic) text and the social heteroglossia surrounding it are more suggestive for the study of the social significance of language in novels than are theories of irreducible stylistic individuality, as argued in, for example, Louis Milic, 'Against the Typology of Styles', Essays on the Language of Literature, ed. Seymour Chatman and Samuel R. Levin (Boston: Houghton Mifflin, 1967) 442-50.

7 James Obelkevich, 'Proverbs and Social History', The Social History of Language, ed. Peter Burke and Roy Porter (Cambridge: Cambridge UP, 1987) 43-72, esp. 55-59.

8 The Guardian, ed. James Calhoun Stephens (Lexington, KY: Kentucky UP, 1982) 112. The date of this paper is 8 April 1713.

9 Philip Dormer Stanhope, Lord Chesterfield, The Letters of Philip Dormer Stanhope 4th Earl of Chesterfield, ed. Bonamy Dobree, 6 vols. (London: Eyre and Spottiswode, 1932) 4: 1407. The letter is dated September 27, O. S. 1749. J. H. Neumann has shown that Chesterfield himself occasionally uses proverbs without commenting on their appropriateness in 'Chesterfield and the Standard of Usage', Modern Language Quarterly 7 (1946): 474-75.

10 Jonathan Swift, A Complete Collection of Genteel and Ingenious Conversation in The Prose Works of Jonathan Swift, gen. ed. Herbert Davis, vol. ed. Davis and Louis Landa (Oxford: Basil Blackwell, 1957) 4: 102. 
11 Swift's use of proverbs and his attitude toward the genre are discussed in Mackie L. Jarrell, 'The Proverbs in Swift's Polite Conversation', Huntington Library Quarterly 20 (1956-57): 15-38 and W. B. Carnochan, 'Notes on Swift's Proverb Lore', Yearbook of English Studies 6 (1976): 63-69. The false grounds on which Wagstaff claims the proverb should be 'resumed' at once allow the genre a merit Swift believed it really had and satirize the vacuous but 'polite' speakers on whose behalf the claim is made.

12 John Hughes, 'Of Style', Poems on Several Occasions. With Some Selected Essays in Prose, 2 vol. (London, 1735) 1:253.

13 The Tatler, ed. Donald F. Bond, 3 vol. (Oxford: Clarendon Press, 1987) 2:97.

14 The Spectator, ed. Donald F. Bond, 5 vol. (Oxford: Clarendon Press, 1965) 4:306.

15 Lady Mary Wortley Montagu, The Complete Letters of Lady Mary Wortley Montagu, ed. Robert Halsband, 3 vol. (Oxford: Clarendon Press, 1965-67) 3:97. That part of the literary tradition in which Jacques characterizes a justice by 'wise saws and modern instances' in As You Like It has narrowed to 'saws'.

16 Samuel Richardson, Clarissa. Or, The History of a Young Lady, 3rd ed., 8 vol. (1751; New York: AMS Press, 1990) 4:121.

17 Lady Mary read Lovelace's behaviour with his cousins as another indication of Richardson's ignorance of the modes of high life: 'Such liberties as pass between Mr. Lovelace and his cousins, are not to be excused by the relation.' Letters 3:97.

18 Basil Bernstein, 'Postscript,' Class, Codes and Control (London: Paladin Books, 1973) 264. Except for the postscript, this collection (to which all future reference will be made) reprints the papers in Bernstein's Class, Codes and Control, Volume 1: Theoretical Studies towards a Sociology of Language (London: Routledge and Kegan Paul, 1971).

19 Basil Bernstein, 'A Socio-linguistic Approach to Socialization: With some Reference to Educability,' Class, Codes and Control 175. Compare Roland Barthes' defence of proverbs against the preferred genre for 'bourgeois' sententiousness, the maxim, in 'Myth Today,' Mythologies, trans. Annette Lavers (London: Paladin Books, 1973) 154-55.

20 Basil Bernstein, 'A Socio-Linguistic Approach to Social Learning,' Class, Codes and Control 150.

21 In Bernstein, restricted and elaborated code and positional and personal orientation are independent variables: the present discussion simplifies this schema for reasons of length. There is a brief introduction to elaborated and restricted code in their relation to person-oriented and position-oriented families in Jenny Cook-Gumperz, Social Control and Socialization: A Study of Class Differences in the Language of Maternal Control (London: Routledge and Kegan Paul, 1973) 8-18. The relevance of the personal/positional distinction to Clarissa has been suggested briefly by Ramona Denton, who refers to Mary Douglas, Natural Symbols: Explorations in Cosmology (London: Cresset Press, 1970) -- itself inspired by the work of Bernstein -- in 'Anna Howe and Richardson's Ambivalent Artistry in Clarissa,' Philological Quarterly 58 (1979): 58. Although Roger Fowler applied Bernstein's theory of code (with reservations) in a brief reading of D. H. Lawrence's Sons and Lovers in his introductory Linguistics and the Novel (London: Methuen, 1977) 115-22, there has been little application of Bernstein's theory to literary texts. However, if the theoretical concepts are used to understand relations between speakers and the processes by which social groups are 
constituted, rather than simply in reductive characterization of individuals and groups, and if it is remembered that the precise linguistic markers of 'restriction' and 'elaboration' vary from text to text, they should prove illuminating.

22 For other proverbs or turns of expression attributed to Lord M., see 416, 449, 633, $700,701,814,863,973,1025,1027,1032,1431$ and 1436; for Lovelace's citations of proverbs, see $676,678,687,731,761,781$ and 912 .

23 This analysis uses the systemic-functional grammar of English presented in M. A. K. Halliday, An Introduction to Functional Grammar, 2nd. ed. (London: Edward Arnold, 1994). 'Usuality' is Halliday's term.

24 James Grantham Turner, 'Lovelace and the Paradoxes of Libertinism,' Samuel Richardson: Tercentenary Essays, ed. Margaret Anne Doody and Peter Sabor (Cambridge: Cambridge UP, 1989) 70-88, esp. 73-74.

$25 \mathrm{Mr}$. Harlowe also uses elaborated code in this interview, although because the clearest example is reported rather than quoted -- 'he was pleased to withdraw ... saying that he would not hear me thus by subtlety and cunning aiming to distinguish away my duty, repeating that he would be obeyed' (65) -- the strongest impression is of restriction. Another of Mr. Harlowe's genres for control, the curse, which Abrahams associates with proverbs, taunts and boasts as attempts 'to induce future action through the establishment of the speaker as arbiter of values' (n. 4,56) is discussed in Peter Hynes, 'Curses, Oaths, and Narrative in Richardson's Clarissa,' ELH: A Journal of English Literary History 56 (1989): 311-26.

26 The exercise of personal judgement being carried out through elaborated code, there is a cruel appropriateness to Arabella mocking Clarissa's 'judgement' of which clothes and jewels will best adorn her in marriage to Solmes (203-04).

27 We understand this only when we supplement the passage from her grandfather's will Clarissa quotes at Anna's request early in the novel (53), with Anna's comment that he knew 'the family-failing' (which Anna says he shared) (128) and Belford's comment on Clarissa's being enabled to make a will of her own (1191). The will is thus not an origin of discord, or a sin against strict settlement to which Clarissa's excellence alone has tempted her grandfather: it is a calculated intervention in an ongoing struggle.

28 In his discussion of the remarkably consistent and surprisingly distinct patterns in Lovelace's and Clarissa's habitation of London, Edward Copeland points out that Clarissa lives and writes and dies in Covent Garden, centre of prostitution and site of her ruin; see Copeland's 'Remapping London: Clarissa and the Woman in the Window,' Samuel Richardson: Tercentenary Essays, 51-69.

29 Janet Todd has written perceptively on the limitations of Anna's and Clarissa's friendship in Women's Friendship in Literature (New York: Columbia UP, 1980), ch. 1.

30 Restricted code is thus both the mode in which to appeal to the Harlowes, as Parson Brand does through a high prestige version of restricted code, prolix Latin quotation he assumes the family will read as a sign of intellectual distinction, and it is the mode in which to resist them.

31 In Bernstein's theory, elaborated codes arise as a consequence of the division of labour; he gives a brief and highly schematic historical overview of this process from the middle ages to the present in 'Education, Symbolic Control, and Social 


\section{G.D. Fulton}

Practices,' The Structuring of Pedagogic Discourse: Volume IV Class, Codes and Control (London and New York: Routledge, 1990) 133-64.

32 Ian Watt, The Rise of the Novel (London: Chatto and Windus, 1957) 199; John Richetti, 'Popular Narrative in the Early Eighteenth Century: Formats and Formulas,' The First English Novelists: Essays in Understanding, ed. J. M. Armistead (Knoxville, Tennessee: $U$ of Tennessee $P, 1985) 33$ (the point is made of earlier heroines, but applies equally to Clarissa); Lawrence Stone, The Family, Sex and Marriage in England 1500-1800 (London: Weidenfeld and Nicolson, 1977); Katherine Sobba Green, The Courtship Novel 1740-1820: A Feminized Genre (Lexington, KY: Kentucky UP, 1991); Nancy Armstrong, Desire and Domestic Fiction: A Political History of the Novel (New York: Oxford UP, 1987). 